Bangladesh Journal of Bioethics 2010;1(2):2-6

\title{
EHICAL READING OF PLATOS'S THE REPUBLIC
}

Jose Ma. Ybanez Tomacruz, PhL., EMMB

Professor of philosophy, Philosophy Division, Ateneo de Davao University, E. Jacinto Street, Davao City Philippines

\begin{abstract}
:
The last four books of Plato's THE REPUBLIC manifest fecundity, not simply in terms of books or pages but in terms of topics or themes. Plato in this opus, true to the form of a Socratic disciple, uses the method of the catena -chain. That is, one topic is nexated or interconnected to the other. This is also the reason why I have decided to delve into this paper not in terms of books but thematically, more specifically, those I consider to be major ones. These themes that I deem to be major ones contained in the four books are Plato's notions of human nature and morality, socio-political philosophy, the process of education or learning, and then his epistemology. However, here I have decided to tackle only one, i.e., Plato's notions of human nature and morality. Lastly, let it also be pointed out that all the expository work and critique shared here are all mine, and thus, for any error or shortcoming, the burden is solely mine and not of Plato nor of any other person.
\end{abstract}

Key Terms: Human Nature, Morality, Virtue, Evil

\section{On Human Nature and Morality}

Plato expounded on his view of human nature through the story of Er (2). Er was a warrior who, people thought, died in battle. However, when his body was recovered ten days after the battle, it was still undecomposed. Subsequently, his family first held a wake for him and set to burn his body after two more days. However, two days later, as his body was already on the pyre to be burned, Er revived. Thereafter, Er recounted that during those days when people thought him to be dead, his soul actually went on a journey in the afterlife. He said that his soul was made to come back to his body because he was entrusted with the mission that "he must be the messenger to mankind to tell them of the other world"(3) and that he was commanded "to give ear and observe everything"(3) that he will witness.

It is important to note that Plato, in recounting the tale of Er is using a "myth" to explain his view of human nature. "Myth" not in the usually-conceived sense that a story is simply fictional, ergo not true. Plato uses the "myth" here in the sense that, granting that the story itself may be imaginary, yet the message it conveys carries with it what he considers as a universal truth -i.e., true to everyone and in every manner-. And conveying a universal truth, therefore, the story carries with it, authority. And that because it has authority, ergo, it should/is ought to be believed. Thus, here we can see, that from Plato's perspective, his view of human nature is not just a fallible theory but is already an ex cathedra ideology. That Er is a harbinger of a sacrosanct decree which

humanity should/ought to heed for it is for the sake of humanity's own good: in it lies humanity's salvation and doing otherwise would be damnation. In other words, Plato's view regarding human nature is not only on the factual level but already on the normative or practical. It takes on the force of law, thus it should be obeyed, a categorical imperative. And thus, after Er's account is over, Plato says:

And so, Glaucon, the tale was saved, as the saying is, and was not lost. And it will save us if we believe it, and we shall safely cross the River of Lethe, and keep our soul unspotted from the world. But if we are guided by me we shall believe that the soul is immortal and capable of enduring all extremes of good and evil, and so we shall hold ever to the upward way and pursue righteousness with wisdom always and ever, that we may be dear to ourselves and to the gods both during our sojourn here and when we receive our reward, as the victors in the games go about to gather in theirs. And thus both here and in that journey of a thousand years, whereof I have told you, we shall fare well.(4)

Indeed, in other words, Plato in a sense, by appealing to the authority of the myth, is putting a stamp of unimpeachable imprimatur on his view regarding human nature. 


\section{Bangladesh Journal of Bioethics 2010;1(2):2-6}

Plato says that according to Er, the souls of those who die initially go either to the upper or lower regions the former, heavenly; the latter, still earthly. Those who lived good or virtuous lives are judged to go to the upper region, and those who lived evil lives are adjudged to the lower region. The two groups will stay in their respective regions for a thousand years. On the upper region, the virtuous souls are to enjoy all the heavenly delights as their reward, and those on the lower rungs are also to stay in their region so as to be punished and also to be reformed/or purged of their past evils. When the thousand years have come to pass, those of the two groups are to emerge out of their respective regions so as to be brought to an ascendant level.

The virtuous ones will immediately be admitted into the next ascendant level, albeit, those of the lower regions is another case. As previously stated, those relegated to the lower regions are sent there to be punished and purged of their evil. However, the story says that there are those in the lower regions who "are incurably wicked or... those who have not completed their punishment"(5). These souls, according to the story, will not be allowed to automatically leave their lowly abode even if the prescribed millennial penalty has already elapsed. The ones who will be allowed to leave the lowly regions -for the higher level or heaven- upon completion of the penal term of a thousand years are only those who have been purged of their evil.

As the story progresses, it will be seen that only the said already-righteous and purged souls will be the ones who will be allowed once again to go through another cycle of birth in our temporal world.(+) Or that, for a soul to be temporally reanimated or be subjected through another cycle of temporal life, it should have qualified to do so: the soul is one of virtue.

This point is important, for it shows that Plato believes that all living creatures -at least the sentient ones, i.e., human beings and animals- have-temporal-lives/are-able-to-be-born-in-the-temporal-world precisely because they have good souls in their heavenly

existence. However, another nuance is needed. That is, because the souls have been of virtue prior to their temporal rebirth, it necessarily follows that they also are temporally born of virtue. Not so, according to Plato, as per Er's story.

Er recounted that the righteous and purged souls, upon the passage of a millennium staying in their designated habitations, are subjected to another process before they are again reborn in the world here and now. The said process is somekind of a half-way house. Now, in their new heavenly residence, after their emergence from their respective regions, they are made to individually choose as to what kind of life they individually would want to have in their approaching earth-bound rebirth. I highlighted the word "individually" to emphasize the point that it is each soul who makes the choice for him/herself. Ergo, inasmuch as no one compels anyone to make that specific choice, the individual soul bears sole responsibility for what it will become in its temporal rebirth. Thus the story says:

"Souls that live for a day, now is the beginning of another life cycle of mortal generation where birth is the beacon of death. No divinity shall cast lots for you, but you shall chose your own deity. Let him who falls the first lot first select select a life to which he shall cleave of necessity. But virtue has no master over her, and each shall have more or less of her as he honors her or does her despite. The blame is his who chooses. God is blameless."(6)

It can also be noted that I also highlighted the term "necessity" in the above citation. I did so because the story is also saying that one is also bound to one's individual choice. Thus, whatever one's choice was ante-birth, consequently that is what one shall also necessarily become in the temporal life. Simply put, Plato is saying that what one is in this world, one has become so because one has priorly decided to become so in the ante-life. This point is germane because its implication is that, if one made a bad or wrong choice in the ante-birth, one cannot anymore have the chance to lead a virtuous life here in the temporal sphere. One can only change again for the better only after one dies and his/her soul is sent to that earlier mentioned lower region and its subsequent possible release to the heavenly abode upon completion of a millennial purgation. Thus this also implies that one who leads a life of evil is worthless, i.e., negated of any positive value. Inferentially, therefore, it can be claimed that to kill evildoers or other evil sentient creatures is outrightly justifiable, or could even be considered as an act of charity because by doing so, the said evildoers are even helped to have their chance of redemption hastened. Thus, if one is born evil, one will always be evil, at least until one is still alive in this world, for in such life one "shall cleave of 


\section{Bangladesh Journal of Bioethics 2010;1(2):2-6}

necessity". Redemption for evildoers is simply not possible in this temporal existence. Only after death could one have the chance of redemption.

Such view has another side to it. That is, only those who made the right choices in the ante-life therefore have lives worth living and cultivating in this space-time dimension for they are the only ones who are not predestined or fated to live evil lives. However, as the story of Er unfolded, upon their rebirth, all the souls -both those who made the right and errant choices in the ante-birth- have already forgotten their previous existence. Thus because of such existential amnesia, if persons - whose souls made the right choices in the ante-life- are not properly guided/properly "awakened" as regards their previous lives, they may also become evil, whether caused by human beings or other circumstances. Ergo, evil is not only predestined, but it could also be a result of non-cultivation of the predetermined goodness. However, of course, if one is already priorly evil, one will always be evil despite any guidance in this spatio-temporal existence.

This view of predestined goodness or evil, as the case may be, has another quite ominous implication: that is, therefore everyone is not born equal. What makes the said congenital inequality more sinister is that it is something from which one cannot escape while one is still alive in the here-and-now. Another onerous implication is that, it follows from the preceding implication that therefore the human being is not necessarily born free (and be-free), good (and be-good). That only some are. That there really are human beings who are therefore born evil and thus will always be evil throughout their temporal lives. And this has at least two further severe implications. Firstly, this might eventually prove that one should not necessarily be responsible for one's actions, specially if they are evil. Fate -though of his own ante-life choice- has destined one to be so in this existence. And so no one should even blame the evildoer anymore. $\mathrm{He} / \mathrm{she}$ is simply perfecting what he/she has started even before he/she was conceived. The evildoer's existence is a mistake. The evildoer does not only have a tragic flaw here. He/She is tragedy itself. And it was not his/her fault to that he/she was made to proceed to rebirth despite such fateful affliction. As Er's tale goes, he/she was simply made to proceed to rebirth despite of making the aforementioned wrongful choice. And such mistake cannot be rectified here and now but only in the afterlife. Ergo, the best resort for such an hopeless temporal existence is to kill the evildoer -and with the further implication that through the said death the predestined evil is redressed and the a-priori error in the ante-life is once again in the process of being rectified.

The second severe implication has to do with the existing cornerstone of human jurisprudence: that is, one should not anymore be presumed innocent unless proven otherwise, but instead the reverse. That because one has committed an evil action, therefore one is evil, unless he/she proves otherwise -again with the implication that one is able to do evil because one is of a soul who made the wrong choice in the ante-life. Another insidious consequence of predestined goodness or evil is the justifiability of the preferential treatment to a group of people on the assumption that they are the ones who are born to be virtuous because they are also deemed to have made the right choice in the ante-life. Ergo, discriminations resulting from such preferential treatment are also warrantable. Therefore, only those who have been deemed to have been born to be good are to enjoy rights and privileges in this world. On the other hand, those considered base-born, therefore, based on the preceding arguments, will only have two rights: either to live a life of contempt, or to die. To live a life of miserable contempt for he/he deserves because it is what he/she actually is in the first place. To die, so as to be able to have the chance again to be purged in the after-life, so as to be subsequently able to hopefully make right choices in the following ante-life, so as to subsequently be able to have the chance to become virtuous in one's next cycle of life.

At this juncture, one might already have the impression that I might simply be putting words into Plato's mouth, or charging him with ideas which he himself does not espouse. Let us see.

The story of Er said that the souls made their choices in heaven, and that such choices were irrevocable. Thus being irrevocable, the souls who made wrong choices should be/are destined to live evil temporal lives. And being irrevocably evil lives, thus nothing will ever change it except death. I find such flow of the story logically implausible. The story would have been more sensible if it should have gone in such a manner that the souls should have corrrected or should have been allowed to correct their egregiously erroneous choices in the ante-life. Otherwise, the worldly existence of such Er's story's characters is meaningless, absurd. Meaning that, a storyteller does not put such a situation in a story unless either he/she does so by mistake -a mental lapse- or that she has the deliberate purpose for doing so.

But, I would like to give Plato the benefit of the doubt: that he was not stupid, and thus he did not make a mistake/mental lapse, but instead has some very deliberate purpose in mind. I say very deliberate, for I 
Bangladesh Journal of Bioethics 2010; 1(2):2-6

can't seem to conceive that a person of Plato's caliber, whose extant works are nothing less than brilliant, can make an error in such crucial a point. I think he simply literally meant what he said through the story of Er. I would like to surmise that Plato was indeed simply saying that if one is being so predisposed -ergo in a sense predestined- to evil, therefore one simply makes one's life nothing but being akin to a goingthrough-the-motions-existence, ergo, meaningless/absurd. That having already accepted that one has indeed been predisposed/fated to such, one also at the same time has ceased to struggle to ask, to question such kind of never-ending existential gloom. Therefore, by thinking so, Plato was simply trying to keep faith with his mentor Socrates' credo that "An unexamined life is a life not worth living." In fairness to Socrates however, I think here Plato might have taken his mentor's words to their extreme. Methinks that I should, and I think so too Socrates would, agree with Plato that indeed an evil life is a meaningless life. However, I would like to disagree -and maybe Socrates also would- with Plato that there should only be two options that his paradigm should offer to an evildoer: one, a life worthy solely of contempt, or two, death.

Ergo, again, I think by presenting his notion of human nature through the myth of Er, Plato could have either been culpably stupid -made a monumental mistake-, or that Plato being the classic genius that he was, was simply brilliantly deliberate. In addition, based on my previous discussions, whichever of the two Plato may have been, his appeal to the story of $\mathrm{Er}$ as a myth-expressing-universal-truth-ergo-beingauthoritative is now highly suspect. The way I see it, the myth of Er as such is more of the fictional variant. Therefore, I conclude that Plato's view on human nature -i.e., one is predestined to be either good or evil even before one is conceived- is also of the of the same kind: at minimum, highly questionable.

Finally, through the story of Er, Plato, undeniably, however, also presented something worth positive merit. The story tells here of those souls who made the wrong choices in heaven:

He was one of those who came down from heaven, a man who lived in a well-ordered polity in his former existence, participating in virtue by habit and not by philosophy, and one may perhaps say that a majority of those who were thus caught (i.e., making wrong choices) were of the company that come from heaven, inasmuch as they were unexercised in suffering. But those who came up from the earth, since they themselves suffered and seen suffering of others, did not make their choice precipitately...(7)

The above citation tells us several things. Firstly, that "habitual virtue" is not enough. Habitual virtue, meaning unreflectively repeatedly doing something precisely because we consider it to be ethically good or sought-for, thereby making the said action almost part of our so-called second nature. Plato here shows an insight into the human tendency to do things based on established pattern -and the pattern in turn already unquestionably considered as safe. At the same time, he however posits a challenge to the said habits by saying that one could be "... participating in virtue by habit and not by philosophy...", thereby implying that even our so-called habitual virtues should also be adequately checked or examined either for further buttressing, or for possible amendments, or even for total change. Secondly, that what can really guide to make such checking and correcting is "philosophy" or simply put, reflection. Plato seems to be saying that habits at times could also lead us to self- deception, and unfortunately at times with dire consequences. Ergo, if ever there is a habit which should be so consistently nurtured and cultivated it is that of selfexamination, self-reflection, because as Plato's paragon Socrates said, "An unexamined life is a life not worth living." Thirdly, that as our comfort zones -brought about by habitual inclinations- could dull our capacity for right judgment, inversely, difficulties could hone it. Thus the citation says that "But most of those who came from earth, since they themselves suffered and seen sufferings of others, did not make their choice precipitately..." My observation and experience confirm Plato's point. I have seen that the people who usually panic or wilt in crisis or extreme situations are the ones who lived protected lives. To a large extent, quite a number of people who are products of sheltered upbringing lack that toughness to make even simple decisions, and more so, hard decisions. Simply as a university professor, I have witnessed quite a number of students coming from really prominent families who lived directionless lives. Students who are more focused in their studies -and later in their careers- are usually the ones who come from lower and middle income backgrounds, backgrounds usually characterized by resiliency, hard work, competition. 
Bangladesh Journal of Bioethics 2010;1(2):2-6

\section{REFERENCES}

1. Shorey, P, translator. PLATO: THE REPUBLIC, 2 Vols. First printed, 1930. Cambridge, Mass., and London: Loeb Classical Library; 1953, 1956.

* This paper should not in any way be reproduced without explicit permission or proper citation of the Author.

2. Plato: Republic, 614b-621b.

3. $614 \mathrm{~d}$.

4. $621 \mathrm{c}-\mathrm{d}$.

5. $615 \mathrm{e}$.

+ The Greeks also believe in reincarnation.

6. 617d-e.

7. 619c-d. 